\title{
An Analysis of the Monetary Transmission Mechanism of M\&A, Greenfield FDI, Domestic Investment, and GDP Per Capita Growth: The Structural Vector Correction Model in Indonesia
}

\author{
Albert Hasudungan ${ }^{1}$ Andrey Hasiholan Pulungan² \\ ${ }^{1}$ School of Business and Economics, Universitas Prasetiya Mulya, Indonesia \\ ${ }^{2}$ Universitas Sampoerna, Indonesia
}

\begin{tabular}{l}
\hline ARTICLE INFO \\
\hline Article History \\
Received 21 December 2020 \\
Accepted 31 August 2021 \\
\hline JEL Classifications \\
F20, F21, F47
\end{tabular}

ABSTRACT

Purpose:

The study aims to evaluate the different implications of mergers and acquisitions (M\&A) and Greenfield foreign direct investment in the transmission mechanism effects on the growth of gross domestic product per capita (GDP per capita) in Indonesia. The origin of the study stems from past academic debates that contested whether Greenfield FDI or M\&A bear more effect on the economic growth in emerging markets.

Design/methodology/approach:

The study deployed a structural vector error correction (S-VECM) time series model to evaluate the short-term and long-term effects of M\&A and Greenfield investment effects on the growth of GDP per capita in Indonesia. The research gathered secondary time series data from the first quarter of 2003 until the fourth quarter of 2019. The stages of the economic regression consisted of a stationary test, a co-integration test, an impulse response assessment, and a variance decomposition analysis.

Finding:

The study discovered the significance of the short-term effect of M \& M\&A to stimulate greenfield investment, which then ramps up more domestic investment and GDP growth. However, greenfield investment galvanised a stronger intermediary effect to augment GDP growth per capita over the long-term. This study remarks greenfield investment as the essential mediator to enhance domestic investment and GDP growth in long-term horizon

Research limitations/implications:

Keywords:

M\&A;

Greenfield;

FDI;

GDP per Capita Growth Indonesia
The study stems from past academic discussions that widely tested the exogenous effects of M\&A and Greenfield investment on economic growth by pooling heterogeneous developing and developed countries. This study specifically removed the heterogeneous effects and added an endogenous analysis by devising S-VECM in Indonesia. However, this specific case study cannot reflect the association in other countries in Southeast Asia. More replicated studies can be undertaken on other Southeast Asian countries.

Originality/value:

Firstly, the academic contribution of this research mediates the past academic debates about the relative importance between $\mathrm{M} \& \mathrm{~A}$ and Greenfield to drive economic growth. This study demonstrates the complementary functions of M\&A and Greenfield in different time horizons, respectively in long-term and short-term time horizons. The study synthesizes more negotiating economic considerations of both M\&A and Greenfield investment to affect economic development in different economic horizons. Secondly, this study enriches the econometric analysis by echoing the greenfield investment as the mediator function to stimulate domestic investment and GDP growth per-capita from the shock of M\&A. from the transmission mechanism is on order initiated shock from M\&A, Greenfield investment, domestic investment and then to the growth of GDP per capita. This mechanism transmission was not available in the past academic debates with the panel econometric studies.

${ }^{\dagger}$ Corresponding Author: Albert Hasudungan

Email:albert.hasudungan@pmbs.ac.id 


\section{Introduction}

Indonesia has been attractive emerging economy for foreign direct investment destinations. In 2019, Indonesia was in the third position of the total M\&A and Greenfield investment host countries in Southeast Asia (see Graph 1). Unfortunately, with the COVID-19 pandemic, there has been severe economic shock to attract investments in Southeast Asia. With the economic disruption and restricted mobility from the COVID-19 pandemic, OECD (2020) predicts falling foreign direct investments by $30 \%$ throughout the world in 2020. The remaining question is what kinds of investment options should be prioritised to sustain economic development in Southeast Asia.

\section{Graph 1. FDI \& M\&A in Southeast Asia (in Millions of US Dollars) in 2019}

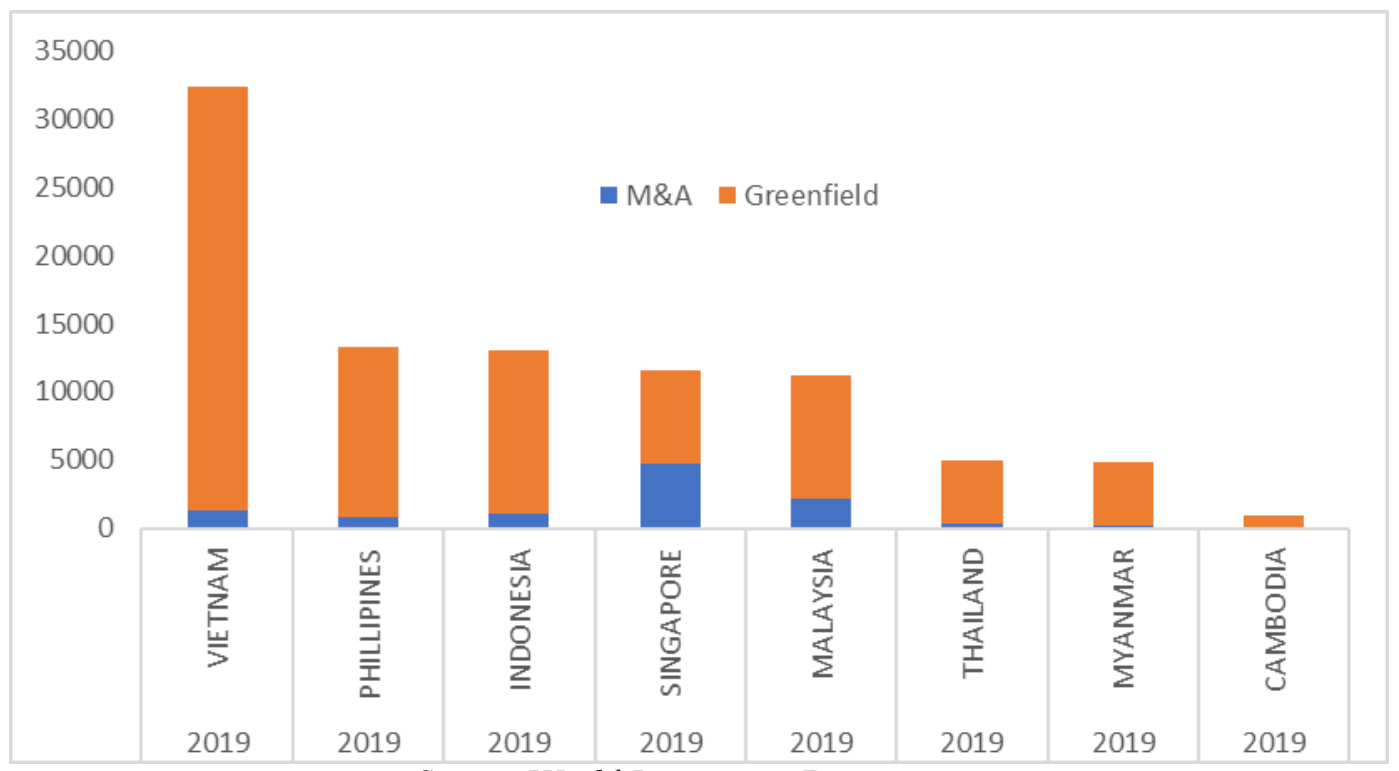

Source: World Investment Report 2020

Note: Brunei Darussalam \& Laos were not reported due to incomplete information

This study has acknowledged wide array investments, including greenfield investment, mergers and acquisition and brownfield investment. However, with the constraint to demote more detailed investment data, especially brownfield investment in southeast Asia, the locus of this study is on M\&A and greenfield investments. Forgoing research have conferred comparison of $\mathrm{M} \& \mathrm{~A}$ and Greenfield investment to uplift economic growth in Southeast Asia. In the past, Aguiar and Gopinath (2002) argued that mergers and acquisitions had solved the illiquid problems of domestic companies during the Asian Crisis in 1997/1998. Given the complexities and reluctance of overseas investors to commit to the total Greenfield investment, M\&A was an considered as viable choice to increase economic growth (Calderón et al., 2004). With panel data, Calderón et al. (2004) confirmed the significant influence of M\&A to drive economic growth throughout the 100 countries. Calderon et al (2004) observed that pattern from 1987 to 2001 , where they asserted in 1987 was a boom of mergers and acquisition in major developing countries.

Later on, Harms and Méon (2018) refuted the idea and found an insignificant influence of M\&A on economic growth due to the limited effect of transfer rent to the previous owner. In their observation, while M \& M\&A has provided substantiated capital. However, they measured from 1990 that the subsequent effects of greenfield investment are pertinent to induce more growth, especially in the Southeast region. Harms and Méon (2018) advocated Greenfield investment since it is associated with economic development contributions from multinational companies to purchase physical capital and trained workers from scratch. However, they overlooked the effect of M\&A to sustain growth permanently. Their premier argument was that the rent from M \& M\&A has adverse effects on surging consumptive expenditure and decelerating long-term productivity. The conflicting perspective among economists related to M\&A sparked more debates in international economics. From the author's perspective, those debates appeared in the past panel data study to aggregate developing economies instead of different economic contexts among the country. This study acknowledges data heterogeneity of developing nations and time frames in panel data regression. Hence, this study examines the transmission of M\&A, greenfield investment, domestic investment, and GDP growth per capita in the short term and long term in Indonesia.

This paper aims to investigate the effects of M\&A and Greenfield investment on the growth of GDP per capita in the short-term and long term. This study benchmarked the past study on availing structural VAR by Nguyen et al. (2020). Nguyen et al. (2020) focused more on one country to remove the heterogeneity characteristics of panel data. Besides that, structural VAR helps to seek that in a series of transmissions. Nguyen et al. (2020) preferred Greenfield investment to M\&A, but they did not separate their analysis in short-term and long-term horizons in Vietnam. To enrich more academic discussions, this study investigates the transmission mechanisms of M\&A, Greenfield 
investment, and domestic investment on the growth of GDP per capita in the short term and long term. From a timeseries perspective, the short term ranges about one year, but the longer term periods are more than three years or more. These short-term and long-term horizons follow previous studies (Calderón et al., 2004; Harms \& Méon, 2018; Nguyen et al., 2020). Hence, The academic contribution of this study is to elaborate on the complementary function of M\&A to drive more GDP per capita growth in the short-term and long term. Greenfield investment has more affected the domestic investment and growth GDP per capita in the long term.

Nevertheless, M\&A is needed in the short term to attract greenfield investment inflow to Indonesia. Secondly, the study frames the observed variables in a structural transmission mechanism rather than just observing the simplistic exogenous effects of M \& M\&A, Greenfield investment, and domestic investment on GDP growth per capita. The theoretical implication is the necessity to investigate the influence of $\mathrm{M} \& \mathrm{~A}$ and greenfield investment on domestic investment and GDP growth per capita from a transmission mechanism perspective. The transmission mechanism exhibits those variables' interdependence rather than the exogenous effects of M\&A and greenfield investment on GDP growth per capita.

The structure of this paper comprises the introduction, literature review, methodology, results, and Conclusion. Firstly, as explained beforehand, the introduction briefly unveils the study's aim and prompts an argument to select the Indonesian economy as a locus. Secondly, the literature review exposes the various academic perspectives over M\&A and Greenfield investment to boost economic growth. Thirdly, the research methodology details the rationale and steps of utilizing S-VECM to expose Indonesian time series data. Furthermore, the result shows the empirical findings of the observed variables. Besides, the conclusion summaries the findings, admires the limitations, and propose a policy recommendation and future research.

\section{Review of Literature}

\subsection{The effect of FDI in economic growth per capita}

In international economics and business literature, investment is composed of portfolio and direct investments. From the macroeconomic perspective, portfolio investment was a short-term investment and bore the uncertainty in the easing investment outflow during the Asian crisis (Krugman et al., 2015). In contrast, foreign direct investment is the permanent investment, where the foreign investor spent their money to embrace their corporate business (Krugman et al., 2015). Due to their investment characteristics to endure permanent capital investments, many prominent economists urge this investment as the driver for economic growth in emerging markets. In fact, for the host country, foreign direct investments may enhance more domestic investments due to their business spillover to extent more domestic entrepreneurship (Harms \& Méon, 2018).

From a microeconomic perspective, FDI is seen by multinational companies as an investment arrangement to enhance their business competitiveness across the global market (Radulescu et al., 2020). Firms from developed countries have branched more of their production and commercial activities overseas, as they view more expensive and saturated market shares in their countries because of the expectation that they will increase their market shares and new business margins with production costs that are cheaper than producing in their own countries (Cavusgil et al., 2020). Many of them have globalized their businesses in emerging markets in Southeast Asia, as the region offers vast market shares and lower production costs (Cavusgil et al., 2020). This configured strategy is undertaken to enhance their competitiveness in the global market, which is meant for foreign direct investments (Baumgarten et al., 2013). Hence, regional FDI is a significant driver to create industrial knowledge spillover in Southeast Asia (Raeskyesa \& Suryandaru, 2020).

With the fast-growing global value chain transformation in emerging markets (Hasudungan \& Raeskyesa, 2021), there has been a mixed consensus on the effects of FDI on growth. Bair (2005) mulled that the production of commercial commodities has decentralized in different countries, not in a single country anymore. Some multinational firms may use M\&A if the intention is to provide more liquid capital to their domestic partners by acquiring those firms, but other firms use Greenfield investment if the intention is to build manufacturing from scratch in that global value chain reality. Furthermore, Harms and Méon (2018) acknowledged past studies to overlook the heterogeneity of FDI, comprising Greenfield investment and mergers and acquisitions (M\&A). Financially, M\&A is associated with rent given to previous owners. However, Greenfield investment does more than that as it injects new physical and human capital investments to the host countries. With this buoyancy, this economic aspiration induces more academic discussions to assess the different effects of M\&A and Greenfield investment on economic growth.

\subsection{The relationship of $M \& A$, domestic investments, and economic growth per capita}

M\&A is an action of foreign companies to purchase the ownership of established domestic firms (Calderón et al., 2004; Cavusgil et al., 2020; Harms \& Méon, 2018). With that particular investment, these multinational companies may have a greater authority to control domestic companies to support their business operations in the host country (Cavusgil et al., 2020). In international economics, the impact of cross-border M\&A on economic growth has been sparking controversies among different economic scholars. The advocates argue for more significant impact mergers and acquisitions to enhance economic growth, but the opposing side rejects that hypothesis.

From the academic supporters, M\&A is associated with several economic benefits in the host countries. Firstly, M\&A drives more business efficiency of previous domestic-owned companies (Aguiar \& Gopinath, 2002; Blomström \& Sjöholm, 1999; Calderón et al., 2004). It was found that foreign acquirers have superior technology and skills 
(Blomström \& Sjöholm, 1999). These foreign companies are believed to transfer their superior technology and skills to their subsidiaries in the host countries (Ibid.). Hence, business operations can improve due to the support from these multinational interventions. Secondly, the advocates of M\&A believe there will be more liquid financial resources with that intervention. Calderón et al. (2004) discovered that M\&A boosts more inflow on the domestic investments. Later, Aguiar and Gopinath (2002) revealed that cross-borders solved some host countries' firms' liquidity problems during the global crisis of 2008. Hence, they concluded that mergers and acquisitions are fire-sale acquisitions to enhance host countries' economic resilience (Aguiar \& Gopinath, 2002). Balsvik and Haller (2010) also found a positive relationship between cross-border M\&A and domestic wages and plan productivity. Ashraf et al. (2016) confirmed those claims by showing a positive impact of the mergers and acquisitions on total factor productivity and economic growth of the host country. The abovementioned reasons embark from the positive influence of M\&A on economic growth.

Conversely, the critics of M\&A demonstrated insignificant M\&A towards the economic growth of the host countries. Firstly, M\&A will be insignificant if the domestic stakeholder's host country cannot utilise it for economic growth. For instance, Wang and Wong (2009) observed the hampering impacts of M\&A if the country does not own sufficient human resource capabilities to absorb multinational spill-overs. Besides that, Eren and Zhuang (2015) elucidate no significant impact of M\&A on economic growth if the country does not have a credible financial system. Secondly, mergers and acquisitions can transfer the rent to previous owners with weak economic spillover to domestic investments and economic growth. For instance, Gopalan et al. (2018) criticized mergers and acquisitions as having a short-term interest in buying domestic firms to transform ownership but limited to drive more technological and institutional development in the host countries. Using panel data of 24 Asian economies, Gopalan et al. (2018) found an insignificant impact of M\&A on economic growth. In addition, Harms and Méon (2018) argued that M\&A is a weak foreign direct investment as it only shows rent accrual for previously owned firms without additional investment impacts. Then, their panel data found a non-significant impact of mergers and acquisitions on host countries' GDP per capita. Besides that, Nguyen et al. (2020) found that M\&A is ineffective as it has a detrimental effect on domestic investments and economic growth in Vietnam.

\subsection{The relationship of Greenfield investment, domestic investment, and growth}

The past assessment between Greenfield investment and a country's economic growth itself is mixed. Greenfield investment in an economic perspective is a multinational firm's investment to build new production from the beginning (Harms \& Méon, 2018). Academic debates have weighed the effects of Greenfield investment on economic growth.

In a previous supporting assessment, Greenfield investment is associated with a more sustainable positive shock to the domestic economy. For instance, Marin and Bell (2006) analysed a positive Greenfield investment with economic growth through a time series multiple regression. In their proposition, the more substantial an investment is in the host country, the more activities will spill knowledge and economic accumulation benefits for the host country. Secondly, Greenfield investment will encourage innovation that in turn induces positive economic growth. For instance, while the effects of FDI on economic growth are heterogeneous in the study of Marin and Sasidharan (2010), there has been a positive correlation of whole capital investment expenditures on FDI rather than a partial investment that is associated with acquiring an existing firm. Besides that, Liu and Zou (2008) tested the association of the impact of Greenfield investment on domestic innovations. They found a significant impact on domestic company innovations from Greenfield investment, whether from within one industrial sector or inter-industrial sectors. From the Keynesian point of view, this domestic investment is fixed gross capital accumulation that can induce more gross domestic product (Kriesler \& Halevi, 2016). Wang and Wong (2009) also demonstrated the significance of the positive relationship between Greenfield investment and economic growth in developed and developing countries. Furthermore, Greenfield investment is associated with new capital investment associated with higher capital to investment rent. For instance, Harms and Méon (2018) found that with new capital investment, there is a significant relationship of Greenfield FDI on the growth of GDP per capita in their panel data estimation in developing countries.

In the opposing view, several studies show the uncertain effects between Greenfield investment and economic growth. Firstly, Calderón et al. (2004) refuted the effect of Greenfield investment on a country's economic development. Using annual data of 1987-2001 of developing and industrial countries, their panel data shows insignificant effects of Greenfield investment on economic development. Hence, they concluded that Greenfield investment has not always fostered economic growth (Calderón et al., 2004). They also argued that Greenfield investment can hamper domestic investment and is unsuitable for countries with low human capital absorption. For instance, Eren and Zhuang (2015) inferred that Greenfield investment has not significantly influenced a country's human resource absorptive capacity. Another insignificant effect of Greenfield investment was also demonstrated in a study by Jude (2019). In her proposition, expanding Greenfield investment exacerbates crowding out of the capital accumulation effect that hampers domestic investment. This argument echoed more negative effects of FDI on domestic investment (Jude, 2019).

The debates focus more on the direct association of M\&A and Greenfield investment. While few literature studies suggested an association with domestic investment (e.g. Liu \& Zou, 2008; Kriesler \& Halevi, 2016), the discussion partially separates the direct effects of those variables to examine the economic growth and GDP per capita. Nonetheless, the limitations of past studies do not show the economic pathways in how M\&A can affect economic growth. Nguyen et al. (2020) observed the shock order of M\&A to Greenfield and then to domestic investment, and then the effect of GDP per capita growth. However, since they did not distinguish the long-term and short-term 
impacts, they saw incompatibility between M\&A and Greenfield investment. This research uses the S-VECM to examine the compatibility between M\&A and Greenfield investment in short-term and long-term periods.

2.4. Economic Transmission M\&A, Greenfield Investment, Domestic Investment, and GDP per capita growth Some studies provide the significant effect of foreign direct investment on inducing domestic investment or GDP growth per capita in Indonesia (Jude, 2019; Verico, 2008; Verico \& Pangestu, 2020). However, there has been deficit research to map the economic transmission of M\&A, Greenfield Investment, domestic investment, and GDP growth per capita. Balsvik \& Haller, (2010) indicates that M\&A can drive more greenfield investment if the transformation resulted in more economic capacity to induce firm productivity. The shortcoming is that Balsvik \& Haller (2010) does not exhibit the implication to domestic investment. Kriesler \& Halevi (2016) assert that fixed gross capital accumulation can induce more gross domestic product. It means that greenfield investment is required more to sustain long-term economic growth(Kriesler \& Halevi, 2016). However, their study does not explore the specific connection between M\&A and Greenfield. Nguyen et al. (2020) assert in Vietnam an interdependence of M\&A, greenfield investment, domestic investment, and GDP per capita growth in Vietnam. The contribution of this study is to scrutinise the interdependent of M\&A, greenfield investment, domestic investment, and GDP growth per capita in Indonesia.

\section{Data, Methodology and Empirical Results}

\subsection{Data}

The data is originated from some credible secondary sources. The Greenfield investment and M\&A data are withdrawn from the series of UNCTAD's World Investment Reports (UNCTAD, n.d.). This study represents a domestic investment by the gross fixed capital formation. GDP per capita and domestic investment were retrieved from the World Bank database (World Bank, n.d.). The researchers were constrained by the limited data of Greenfield and M\&A in a quarter-time series. With those data constraints, this study strove to transform the annual data of M\&A, Greenfield investment, domestic investment, and GDP per capita growth into quarterly reports using quadratic match average methods, as it was conducted from past research (Grossman et al., 2014; Marcellino \& Musso, 2011; Nguyen et al., 2020). The differentiation and logarithmic data transformation were devised to avoid heteroscedasticity and multicollinearity problems (Xu et al., 2016).

\subsection{Methodology}

This research measures the transmission mechanism of M\&A, Greenfield investment, domestic investment, and capita growth with the structural vector error correction model (S-VECM). VECM observes long-term and short-term relationships from availing co-integration in that mechanism transmission (Pesaran et al., 2000). In VECM, the model was evolved based on individual experiments and experiences in observing economic phenomena (Hasudungan, 2006). In S-VECM, the mechanism and order of the variables was developed according to the theories of previous literature (Gujarati \& Porter, 2008). When co-integration takes place, the structural VAR (vector autoregression) is transformed into a structural analysis of the vector error correction model (Letson \& Carter, 2009). Specifically, data is transformed in the first difference in S-VECM (Letson \& Carter, 2009), as follows:

$$
\Gamma \Delta \mathbf{y}_{t}=\alpha\left((1-\beta) \mathbf{y}_{t-1}+\mu+\delta t_{t-1}\right)+\sum \boldsymbol{B}_{i} \Delta \mathbf{y}_{t-i}+\mathbf{G} \mathbf{x}_{t}+\boldsymbol{\varepsilon}_{t}
$$

This equation is in a matrix format. In the equation, $\Gamma$ stands for the matrix of the contemporaneous effects of the vector variables of $\mathrm{y}$, given the influence of the vector of variables of $\mathrm{x}$. The difference transformation of the observed variable is denoted with $\Delta$. The co-integrating effect is shown as $\boldsymbol{B}$. In that equation, $\beta$ is the long-run co-integrating relationship, while $\Delta$ donates for the first difference of vector variables.

In the structural vector error correction model, the initiated shock is function of function of the past inter-temporal shocks in n-lag time (Hashem, 2016). In the past study, M\&A has been identified as initiated shock in the transmission mechanism of greenfield investment, domestic investment and GDP (Nguyen et al., 2020). Nonetheless, in the dynamic time series framework, this initiated shock functions of past vector variables and cointegrating variables to exemplify the vector error correction model (Fukuda \& Dahalan, 2012). Modified into the equation will be that the current merger is subject to influence past merger, cointegrating factor, $1 t$, and error, $e_{i t}$, as follow:

$$
\Delta M A_{t}=\sum_{j=1}^{p-1} b_{11 j} \Delta M A_{t-j}+{ }_{1 t}+e_{1 t}
$$

Overtime, the existence of merger is pathway foundation for the firm to deliver greenfield investment. Hence, with that stable merger in place, there are more convincing investment climate to deliver greenfield investment (Balsvik \& Haller, 2010). The influence of the past mergers and past greenfield investment will influence the condition of the current greenfield investment (Nguyen et al., 2020). Reflected into the equation and considering the cointegration, and the error this would be as follow: 


$$
\Delta \text { Greenfield }_{t}=\sum_{j=1}^{p-1} b_{21 j} \Delta M A_{t-j}+\sum_{j=1}^{p-1} b_{22 j} \Delta \text { Greenfield }_{t-j}+\quad{ }_{2 t}+e_{2 t}
$$

This greenfield investment will give the shock as hypothesised in the intertemporal time series perspective to domestic investment (Grossman et al., 2014; Nguyen et al., 2020). With that mechanism in place, the current domestic investment is endogenous function of the past greenfield investment, merger and acquisition, domestic investment, and error $e_{i t}$. That relationship will be symbolized as follow:

$$
\Delta \text { Domestic }_{t}=\sum_{j=1}^{p-1} b_{31 j} \Delta M A_{t-j}+\sum_{j=1}^{p-1} b_{32 j} \text { Greenfield }_{t-j}+\sum_{j=1}^{p-1} b_{33 j} \Delta \text { Domestic }_{t-j}+\quad{ }_{3 t}+e_{3 t}
$$

As the investment target is the GDP, then greenfield investment will influence domestic investment in the long run. Later on, domestic investment will lead to higher GDP and growth (Kriesler \& Halevi, 2016; Nguyen et al., 2020). Therefore, the equation will be as follow:

$$
\begin{aligned}
& \Delta G D P_{t}=\sum_{j=1}^{p-1} b_{41 j} \Delta M A_{t-j}+\sum_{j=1}^{p-1} b_{42 j} \Delta \text { Greenfield }_{t-j}+ \\
& \sum_{j=1}^{p-1} b_{43 j} \Delta \text { Domestic }_{t-j}+\sum_{j=1}^{p-1} b_{44 j} \Delta G D P_{t-j}+{ }_{3 t}+e_{4 t}
\end{aligned}
$$

Elaborating from that equation, vector error correction matrix can be structured with the first difference, hypothetical parameters, cointegrating factor, and error (IHS Markit, 2017). Then, the matrix function will be as follow:

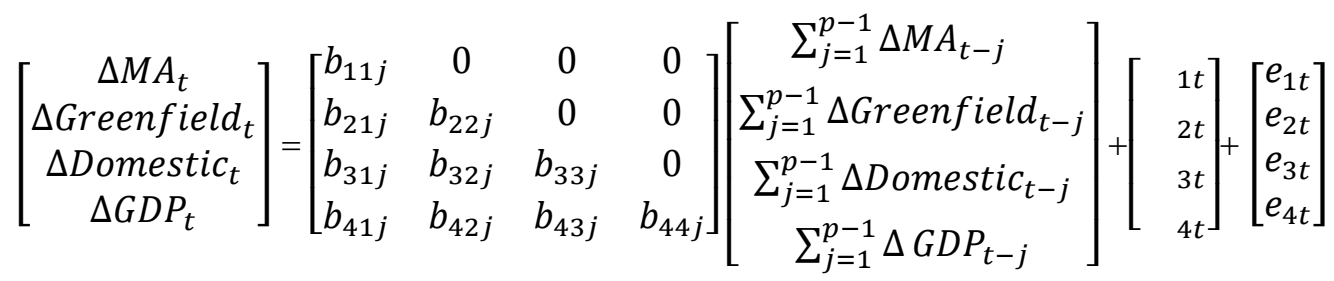

The data is originated from some credible secondary sources. The Greenfield investment and M\&A data are withdrawn from the series of UNCTAD's World Investment Reports (UNCTAD, n.d.). This study represents a domestic investment by the gross fixed capital formation. GDP per capita and domestic investment were retrieved from the World Bank database (World Bank, n.d.). The researchers were constrained by the limited data of Greenfield and M\&A in a quarter-time series. With those data constraints, this study strove to transform the annual data of M\&A, Greenfield investment, domestic investment, and GDP per capita growth into quarterly reports using quadratic match average methods, as it was conducted from past research (Grossman et al., 2014; Marcellino \& Musso, 2011; Nguyen et al., 2020). The differentiation and logarithmic data transformation were devised to avoid heteroscedasticity and multicollinearity problems (Xu et al., 2016).

\subsection{Empirical Results}

Several examinations were conducted to assess the impacts of cross-border M\&A and Greenfield investment towards domestic investment and GDP growth per capita. They included stationary, co-integration, lag length criteria, vector error correction, impulse response, and variance decomposition assessments.

\subsubsection{Stationary Test}

One of the issues when estimating short-term and long-term impacts in a time series is non-stationary data. This nonstationary data will result to spurious econometric result. Aside of that (Mills, 2019) the model is not robust when non-stationary variables are estimated with a stationary econometric model. To overcome that, a stationary test was first examined in those observed variables by using an Augmented Dickey Fuller (ADF) test. There are different levels to test from the original data, first difference, and then second difference (Enders, 2014). Stationarity is important to assure that the probability of statistics does not change over time in the time series data processing (Enders, 2014; Gujarati \& Porter, 2008).

The stationary data indicates no random walk or a non-consistent trend (Mills, 2019). If the variables are nonstationary, the probability of the ADF test will be higher than 0.05. From the following table, the variables did not have stationary properties in the original (level) data format, except for the domestic investment variable, as in Table 1. The solution was to transform it into the first difference. The stationary tests were reconstructed in the first difference data. The assessment shows the stationarity in the first difference degree, as seen in Table 2.

Table 1: Stationary Test in the Level (Original Data)

\begin{tabular}{|c|c|}
\hline Variables & Prob-ADF Test (Ho: Data has a unit root) \\
\hline Merger & 0.1633 \\
\hline Greenfield & 0.3603 \\
\hline Domestic Investment & 0.0083 \\
\hline
\end{tabular}


Source: Constructed from the data

Table 2: Stationary Test in the First Difference

\begin{tabular}{|c|c|}
\hline Variables & Prob-ADF Test \\
\hline Merger & 0.0070 \\
\hline Greenfield & 0.0180 \\
\hline Domestic Investment & 0.0060 \\
\hline Growth of GDP per Capita & 0.0034 \\
\hline
\end{tabular}

Source: Constructed from the data

\subsubsection{Co-integration Test}

In econometrics, when a non-stationary data pattern exists, the alternative solution to avoid spurious regression is to examine a long-term relationship among the observed variables (Enders, 2014). In the stationary data as table 2 above, the stationarity in level occurred in solely domestic investment, the other is on the first difference stationarity. The detected co-integration suggests a co-integration model (a long-term relationship). In this study, the cointegration was scrutinised by using the Johansen co-integration test. It was tested first examined the co-integration test on those MA, GDP, and Greenfield Investment. Our findings suggest no cointegration among those MA, GDP and Greenfield Investment as shown in Table 3.

Table 3: No-cointegration among of MA, GDP, and Greenfield Investment (Original Data)

Unrestricted Cointegration Rank Test (Trace)

\begin{tabular}{|c|c|c|c|c|}
\hline $\begin{array}{c}\text { Hypothesized } \\
\text { No. of CE(s) }\end{array}$ & Eigenvalue & $\begin{array}{c}\text { Trace } \\
\text { Statistic }\end{array}$ & $\begin{array}{c}0.05 \\
\text { Critical Value }\end{array}$ & Prob.*** \\
\hline None & 0.270417 & 33.13608 & 35.01090 & 0.0784 \\
\hline At most 1 & 0.144425 & 12.32746 & 18.39771 & 0.2854 \\
\hline At most 2 & 0.030329 & 2.032705 & 3.841466 & 0.1539 \\
\hline
\end{tabular}

Trace test indicates no cointegration at the 0.05 level

* denotes rejection of the hypothesis at the 0.05 level

**MacKinnon-Haug-Michelis (1999) p-values

Unrestricted Cointegration Rank Test (Maximum Eigenvalue)

\begin{tabular}{|c|c|c|c|c|}
\hline $\begin{array}{l}\text { Hypothesized } \\
\text { No. of CE(s) }\end{array}$ & Eigenvalue & $\begin{array}{c}\text { Max-Eigen } \\
\text { Statistic }\end{array}$ & $\begin{array}{c}0.05 \\
\text { Critical Value }\end{array}$ & Prob.*** \\
\hline None & 0.270417 & 20.80861 & 24.25202 & O.1339 \\
\hline At most 1 & 0.144425 & 10.29476 & 17.14769 & 0.3706 \\
\hline At most 2 & 0.030329 & 2.032705 & 3.841466 & 0.1539 \\
\hline
\end{tabular}

Max-eigenvalue test indicates no cointegration at the 0.05 level

* denotes rejection of the hypothesis at the 0.05 level

**MacKinnon-Haug-Michelis (1999) p-values 
Nonetheless, when the domestic investment is included, as shown in Table 4, the eignvalue and the trace test found co-integration among the observed variables. This study suggests that to weigh the influence of M\&A and Greenfield, the panel data estimation is insufficient, as proposed in previous studies (Calderón et al., 2004; Harms \& Méon, 2018). It then requires more structural chain economic analysis, as this study initiated with the vector error correction model.

Table 4: Cointegration among all variables (Original Data)

\begin{tabular}{|c|c|c|c|c|}
\hline Hypothesized & & Trace & 0.05 & \\
\hline No. of $\mathrm{CE}(\mathrm{s})$ & Eigen Value & Statistic & Critical Value & Prob.*** \\
\hline None $*$ & 0.400374 & 59.61474 & 47.85613 & 0.0027 \\
\hline At most 1 & 0.221819 & 26.37056 & 29.79707 & 0.1180 \\
\hline At most 2 & 0.129095 & 10.06877 & 15.49471 & 0.2755 \\
\hline At most 3 & 0.016543 & 1.084308 & 3.841466 & 0.2977 \\
\hline Hypothesized & & Max-Eigen & 0.05 & \\
\hline No. of CE $(\mathrm{s})$ & Eigen Value & Statistic & Critical Value & Prob.*** \\
\hline None ${ }^{*}$ & 0.400374 & 33.24418 & 27.58434 & 0.0084 \\
\hline At most 1 & 0.221819 & 16.30178 & 21.13162 & 0.2077 \\
\hline At most 2 & 0.129095 & 8.984466 & 14.26460 & 0.2875 \\
\hline At most 3 & 0.016543 & 1.084308 & 3.841466 & 0.2977 \\
\hline \multicolumn{5}{|c|}{$\begin{array}{l}\text { The table provides the results of the trace test and the Max-Eigen value test. Both tests indicate } 1 \text { co-integrating equation at the } 0.05 \text { level. } \\
\text { denotes rejection of the hypothesis at the } 0.05 \text { level }\end{array}$} \\
\hline *MacKinnon-Haug-I & 1999) p-values & & & \\
\hline
\end{tabular}

Source: Constructed from the data

\subsubsection{Lag Length Selection}

In econometric studies, if the econometric model owns inappropriate lag structures, it tends to be biased and has inefficient estimation problems (Song \& Witt, 2006; Xu et al., 2016). If the lag is too short, the data does not generate autoregressive processing, but if the lag is too large, the equation suffers from a lack of the degree of freedom and unreliable estimations (Song \& Witt, 2006). With those considerations, this study discovered the best lags to be used in the econometric regression. From that assessment, it was found that the most stable lag was 2 lags, as shown in Table 5 .

Table 5: Lag Selection Criteria

\begin{tabular}{|c|c|c|c|c|c|c|}
\hline $\mathrm{Lag}$ & $\log \mathrm{L}$ & $\mathrm{LR}$ & $\mathrm{FPE}$ & $\mathrm{AIC}$ & $\mathrm{SC}$ & $\mathrm{HQ}$ \\
\hline $\mathrm{O}$ & 179.9348 & NA & $9.42 \mathrm{e}-07$ & -5.361662 & -5.262132 & -5.322333 \\
\hline 1 & 919.9456 & 1390.323 & $2.26 \mathrm{e}-16$ & -27.51350 & -27.11538 & -27.35619 \\
\hline 2 & 983.8411 & $114.2374^{*}$ & $4.29 \mathrm{e}-17^{*}$ & $-29.17700^{*}$ & $-28.48030^{*}$ & $-28.9017 \mathrm{O}^{*}$ \\
\hline \multicolumn{7}{|c|}{ * Indicates a lag order selected by the criterion } \\
\hline \multicolumn{7}{|c|}{ LR: sequential modified LR test statistic (each test at a $5 \%$ level) } \\
\hline \multicolumn{7}{|c|}{ FPE: Final prediction error } \\
\hline \multicolumn{7}{|c|}{ AIC: Akaike information criterion } \\
\hline \multicolumn{7}{|c|}{ SC: Schwarz information criterion } \\
\hline HQ: Hanr & uinn informa & criterion & & & & \\
\hline
\end{tabular}

Source: Constructed from the data 
Also, in Graph 2, to prompt lags stability, this study examined it with AR-Inverse Root. The lag is stable if the dots were located in the inner circle (IHS Markit, 2017). From Graph 2, the stability of the lag of 2 was obvious as the data was located in the inner circle of the AR-Inverse Root Polynomial Graph. Hence, the structural vector error correction model was generated with a lag of 2 .

\section{Graph 2. Inverse Root of the AR Polynomial}

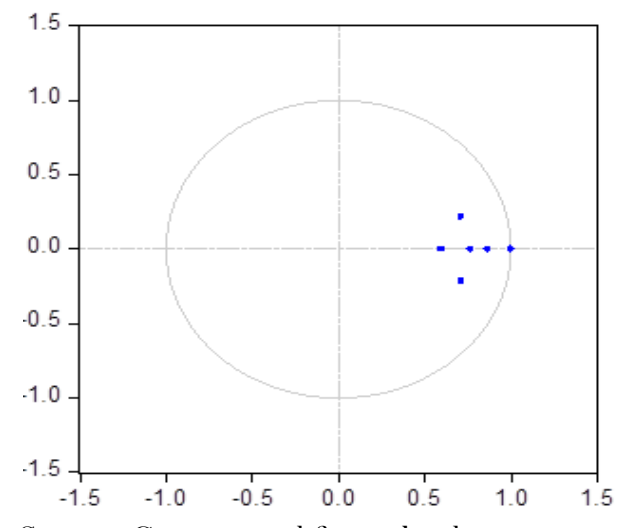

Source: Constructed from the data

\subsubsection{Structural Vector Error Correction Model}

With the structural vector error correction model, the order of the variables (Cholesky variable order) was decided from the past studies or models (Letson \& Carter, 2009). Based on the past literature reviews (Calderón et al., 2004; Nguyen et al., 2020), the shock of M\&A will influence Greenfield investment, domestic investment, and GDP growth. The S-VECM showed the short-term and co-integrating effects.

In the short-term effects, as mapped out in columns 3 and 4, the domestic investment and GDP per capita growth variation was explained positively by the Greenfield investment from the first two periods. However, a reverse relationship between mergers and domestic growth and the growth of GDP per capita existed. In the long-term horizon, however, the shock of M\&A will reduce domestic investment and economic growth. The impulse response and variance decomposition analysis in the following sub-sections explained the short-term and long-term shock impacts. 
Table 6: Structural Vector Equation Model

\begin{tabular}{|c|c|c|c|}
\hline Cointegrating Eq: & CointEq1 & & \\
\hline GREENFIELD $(-1)$ & 1.000000 & & \\
\hline \multirow{3}{*}{$\begin{array}{l}\text { DOMESTIC }(-1) \\
\end{array}$} & -0.505276 & & \\
\hline & $(0.37819)$ & & \\
\hline & {$[-1.33603]$} & & \\
\hline \multirow[t]{3}{*}{ GDPCAPGROWTH(-1) } & 0.082103 & & \\
\hline & $(0.03814)$ & & \\
\hline & {$[2.15285]$} & & \\
\hline$\overline{\mathrm{C}}$ & -0.532595 & & \\
\hline Error Correction: & $\begin{array}{l}\mathrm{D} \text { (GREENFIELD) } \\
\end{array}$ & $\begin{array}{l}\text { D(DOMESTIC) } \\
\end{array}$ & $\begin{array}{l}\mathrm{D} \text { (GDPCAPGROWTH) } \\
\end{array}$ \\
\hline \multirow[t]{3}{*}{ CointEq1 } & -0.184770 & -0.004769 & -0.015831 \\
\hline & $(0.05606)$ & $(0.02849)$ & $(0.01738)$ \\
\hline & {$[-3.29613]$} & {$[-0.16743]$} & {$[-0.91092]$} \\
\hline \multirow[t]{3}{*}{ "D(GREENFIELD(-1)) } & 0.466472 & 0.006246 & -0.005547 \\
\hline & $(0.12499)$ & $(0.06352)$ & $(0.03875)$ \\
\hline & {$[3.73194]$} & {$[0.09833]$} & {$[-0.14315]$} \\
\hline \multirow[t]{3}{*}{ 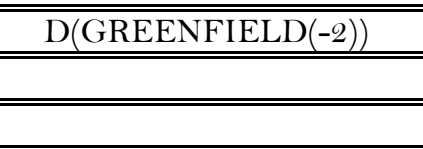 } & 0.216503 & -0.001169 & -0.007041 \\
\hline & $(0.13403)$ & $(0.06811)$ & $(0.04155)$ \\
\hline & [1.61539] & {$[-0.01717]$} & {$[-0.16946]$} \\
\hline \multirow[t]{3}{*}{$\begin{array}{l}\mathrm{D}(\mathrm{DOMESTIC}(-1)) \\
\end{array}$} & 0.262660 & 0.568735 & -0.016635 \\
\hline & $(0.41437)$ & $(0.21056)$ & $(0.12846)$ \\
\hline & {$[0.63388]$} & {$[2.70101]$} & {$[-0.12950]$} \\
\hline \multirow[t]{3}{*}{ "D(DOMESTIC $(-2))$} & -0.331226 & 0.119462 & -0.049126 \\
\hline & $(0.38624)$ & $(0.19627)$ & $(0.11974)$ \\
\hline & {$[-0.85755]$} & {$[0.60866]$} & {$[-0.41026]$} \\
\hline \multirow[t]{3}{*}{$\begin{array}{l}\text { D(GDPCAPGROWTH( }(-1)) \\
\end{array}$} & -0.450845 & -0.042861 & 0.524804 \\
\hline & $(0.68106)$ & $(0.34609)$ & $(0.21114)$ \\
\hline & {$[-0.66197]$} & {$[-0.12385]$} & {$[2.48554]$} \\
\hline \multirow[t]{3}{*}{ "D(GDPCAPGROWTH(-2)) } & 0.544138 & 0.013916 & 0.135561 \\
\hline & $\begin{array}{l}(0.60406) \\
\end{array}$ & $(0.30696)$ & $(0.18727)$ \\
\hline & {$[0.90080]$} & {$[0.04534]$} & {$[0.72388]$} \\
\hline \multirow[t]{3}{*}{$\mathrm{C}$} & -0.000773 & 0.000607 & 0.003501 \\
\hline & $(0.00406)$ & $(0.00206)$ & $(0.00126)$ \\
\hline & {$[\overline{[-0.19042]}$} & {$[0.29426]$} & {$[2.78171]$} \\
\hline \multirow[t]{3}{*}{$\begin{array}{l}\text { MERGER } \\
\end{array}$} & -0.100962 & -0.042162 & 0.008728 \\
\hline & $\begin{array}{c}(0.16983) \\
\end{array}$ & (0.08630) & $\begin{array}{c}(0.05265) \\
\end{array}$ \\
\hline & {$[-0.59448]$} & {$[-0.48855]$} & [0.16577] \\
\hline R-squared & 0.384656 & 0.441669 & 0.430433 \\
\hline Adj. R-squared & 0.296749 & 0.361907 & 0.349066 \\
\hline Sum sq. resids & 0.000873 & 0.000225 & $8.39 \mathrm{E}-05$ \\
\hline S.E. equation & 0.003948 & 0.002006 & 0.001224 \\
\hline F-statistic & 4.375742 & ב5.537358 & (5.290040 \\
\hline Log likelihood & 20272.3598 & ב316.3629 & 398.4827 \\
\hline Akaike AIC & "-8.103378 & -9.457320 & -10.44562 \\
\hline "Schwarz SC & -7.802309 & -9.156251 & -10.14455 \\
\hline Mean dependent & -0.000322 & 0.001049 & 0.010076 \\
\hline
\end{tabular}


Source: Constructed from the data

\subsubsection{Impulse Response Analysis}

Impulse response graphics were visualised to clarify the relationship between M \& M\&A, Greenfield investment, domestic investment, and the growth of GDP per capita. In the equation system, mergers and acquisitions were treated as a nascent shock to transmit to other endogenous variables.

In the short-term perspective, the injection of M\&A will give a positive shock to investment (see the first two quarters in part D of graph 2). In that short-term perspective, M\&A functions to stabilise domestic investment and temporarily increase the GDP per capita. In a past study, Aguiar and Gopinath (2002) asserted the function of M\&A to solve some illiquid problems of domestic companies. Calderón et al. (2004) confirmed the significance of M\&A in the short-term. This empirical study prevailed over previous findings in the short-term.

In the long-term perspective, the shock of M\&A was associated with declining domestic investment and fluctuating GDP per capita growth. Despite that decline, sustaining the increase of foreign direct investment in Indonesia corrected the M\&A failure in the long-term. The rising Greenfield investment in the long-term (see after quarter 3 in graph 3, part D) was associated with a rebounding increase of the domestic investment and GDP growth per capita. The past studies asserted the long-term economic effects of economic spillover and human capital upgrading from the Greenfield investment (Harms \& Méon, 2018; Nguyen et al., 2020). This long-term spillover effect happened in these empirical econometrics results. A more detailed variation of that shock can be clarified from the variance decomposition analysis.

\section{Graph 3. Impulse Response Analysis as a Shock from M\&A and Greenfield Investment}

Response of Greenfield to M\&A

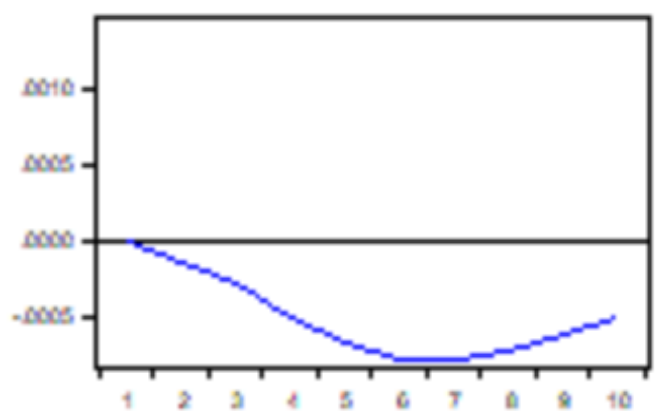

B

Response of Domestic Investment to M\&A

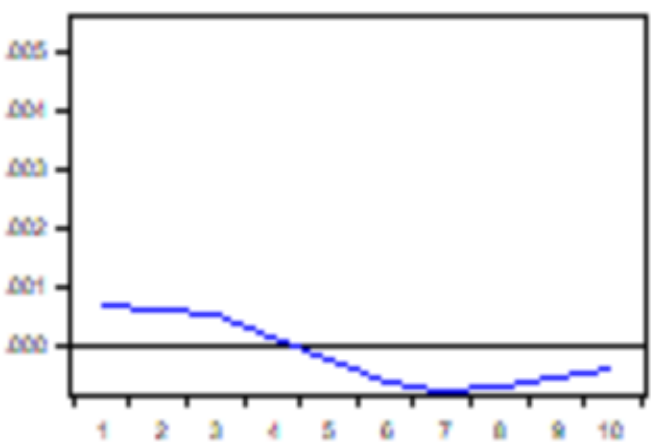

$\mathrm{C}$

Response of GDP per Capita Growth to M\&A

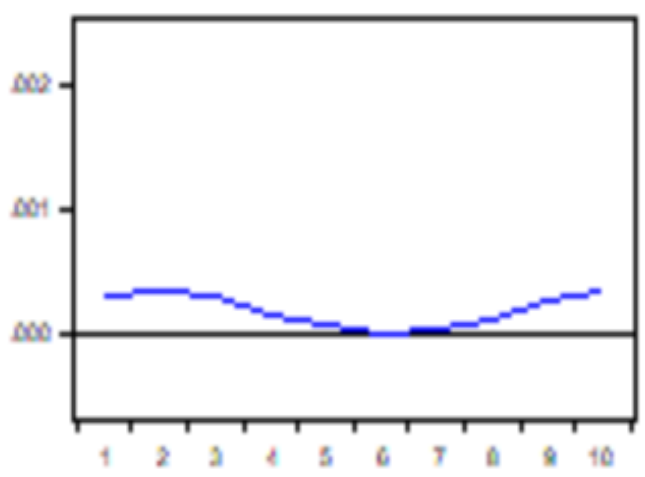

$\mathrm{D}$

Response of Greenfield to Greenfield Investment

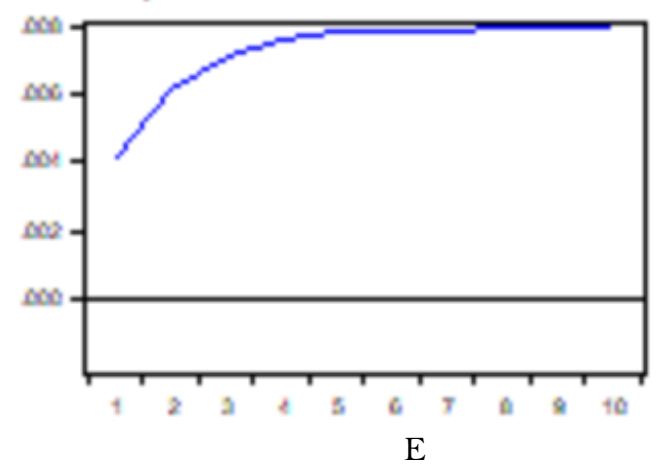

Response of Domestic Investment to M\&A

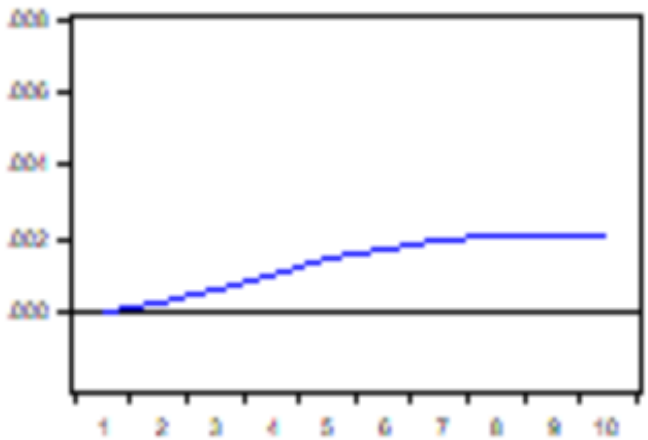


$\mathrm{F}$

Response GDP per Capita Growth to Domestic

Investment

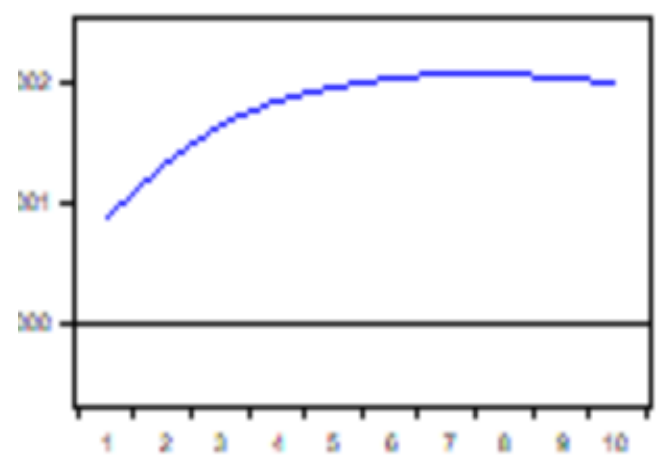

Source: Constructed from the data

\subsubsection{Variance decomposition analysis}

Variance decomposition statistics were further established to validate the impulse response analysis. The variance decomposition data was deployed to trace some variables' short-term and long-term forecast error variation to the observed variables (Nguyen et al., 2020). The observed variables consisted of the growth of GDP per capita and domestic investment.

In scrutinising the effects of M\&A and Greenfield investment on the growth of GDP per capita, this study classified the short-term and long-term analyses. From Table 6, it was obvious that the variation of GDP per capita was influenced more by the variance error shock of M\&A than the Greenfield investment in the first four quarters (see Table 6). Nonetheless, in the long-term, there has been a declining influence of M\&A and an increasing influence of Greenfield investment to explain the variation of GDP per capita growth. Rather than examine the objections of supporters (e.g., Aguiar \& Gopinath, 2002; Calderón et al., 2004) and oppositions (e.g., Harms \& Méon, 2018), this decomposition asserted the complementary function of M\&A in the short-term while underscoring the necessity of more Greenfield investment for long-term economic development. Due to the stronger effect of $M \& M \& A$ in the short-term, while Greenfield investment had a stronger influence to drive more GDP per capita growth in the long term. Hence, domestic investment had the strongest influence on GDP growth per capita, as shown in Table 7 .

Table 7: Variance Decomposition Growth of GDP per Capita

\begin{tabular}{cccccc} 
Period & S.E. & MERGER & GREENFIELD & DOMESTIC & GDPCAPGROWTH \\
\hline 1 & 0.001158 & 8.507603 & 0.321002 & 47.83005 & 43.34134 \\
2 & 0.002120 & 5.999154 & 0.995731 & 41.14660 & 51.85851 \\
3 & 0.003000 & 3.922604 & 2.137828 & 35.03942 & 58.90015 \\
4 & 0.003811 & 2.581011 & 3.664259 & 29.56654 & 64.18819 \\
5 & 0.004565 & 1.811798 & 5.397666 & 24.89543 & 67.89510 \\
6 & 0.005270 & 1.363210 & 7.169704 & 21.06700 & 70.40009 \\
7 & 0.005931 & 1.092153 & 8.869090 & 18.00153 & 72.03723 \\
8 & 0.006552 & 0.944959 & 10.44015 & 15.57188 & 73.04301 \\
9 & 0.007138 & 0.889193 & 11.86435 & 13.65210 & 73.59437 \\
10 & 0.007692 & 0.887368 & 13.14135 & 12.13453 & 73.83675 \\
11 & 0.008216 & 0.904738 & 14.27562 & 10.93186 & 73.88778 \\
12 & 0.008712 & 0.919900 & 15.27053 & 9.974669 & 73.73750 \\
13 & 0.009183 & 0.925472 & 16.12862 & 9.208410 & 73.63265 \\
14 & 0.009630 & 0.922479 & 16.85445 & 8.590419 & 73.54102 \\
15 & 0.010056 & 0.914726 & 17.45677 & 8.087481 & 73.47165 \\
16 & 0.010462 & 0.905666 & 17.94879 & 7.673890 & 73.42596 \\
17 & 0.010850 & 0.897387 & 18.34671 & 7.329944 & 73.40091 \\
18 & 0.011222 & 0.890672 & 18.66773 & 7.040686 & 73.39160 \\
19 & 0.011579 & 0.885439 & 18.92814 & 6.794822 & 73.39289 \\
20 & 0.011924 & 0.881219 & 19.14209 & 6.583797 &
\end{tabular}

Source: Constructed from the data 
Table 8: Variance Decomposition Growth of Domestic Investment

Period S.E. MERGER GREENFIELD DOMESTIC GDPCAPGROWTH

\begin{tabular}{|c|c|c|c|c|c|}
\hline 1 & 0.001828 & 15.18070 & 0.731707 & 84.08759 & 0.000000 \\
\hline 2 & 0.003238 & 12.16321 & 0.905526 & 86.89804 & 0.033217 \\
\hline 3 & 0.004361 & 8.884079 & 1.080423 & 89.92060 & 0.114895 \\
\hline 4 & 0.005221 & 6.428712 & 1.275480 & 92.05271 & 0.243097 \\
\hline 5 & 0.005874 & 5.107989 & 1.510797 & 92.96833 & 0.412880 \\
\hline 6 & 0.006360 & 4.587077 & 1.799545 & 92.99737 & 0.616004 \\
\hline 7 & 0.006708 & 4.398696 & 2.135566 & 92.62370 & 0.842041 \\
\hline 8 & 0.006947 & 4.273033 & 2.487163 & 92.16124 & 1.078567 \\
\hline 9 & 0.007107 & 4.146022 & 2.806283 & 91.73552 & 1.312174 \\
\hline 10 & 0.007212 & 4.036958 & 3.050408 & 91.38156 & 1.531073 \\
\hline 11 & 0.007280 & 3.961659 & 3.202005 & 91.10880 & 1.727536 \\
\hline 12 & 0.007324 & 3.915253 & 3.272093 & 90.91417 & 1.898488 \\
\hline 13 & 0.007354 & 3.886071 & 3.288616 & 90.78087 & 2.044448 \\
\hline 14 & 0.007373 & 3.866105 & 3.280689 & 90.68519 & 2.168015 \\
\hline 15 & 0.007387 & 3.851663 & 3.268499 & 90.60718 & 2.272658 \\
\hline 16 & 0.007398 & 3.840933 & 3.261366 & 90.53577 & 2.361931 \\
\hline 17 & 0.007406 & 3.832739 & 3.260937 & 90.46730 & 2.439028 \\
\hline 18 & 0.007412 & 3.826371 & 3.265408 & 90.40163 & 2.506595 \\
\hline 19 & 0.007417 & 3.821436 & 3.272423 & 90.33942 & 2.566719 \\
\hline 20 & 0.007421 & 3.817629 & 3.280289 & 90.28106 & 2.621022 \\
\hline
\end{tabular}

Source: Constructed from the data

Table 8 above shows this study's further investigation to explore the drivers of domestic investment. This study found that mergers on domestic investment had a dominant effect on domestic investment in the short term. However, their influence had sluggish the longer term. When tracing the long-term horizon, the stronger effect of the Greenfield investment to domestic investment was apparent. That movement underscored the significance of the mediator effect of that Greenfield investment to sustain the domestic investment in the long-term to offset the eroding influence of $M \& A$ that had been dominant in the short-term horizon.

\subsubsection{Robust Assessment}

The VECM model is robust when the model does not posit unstable error disturbance (Enders, 2014). The model stability property is met when their variances are not overshot (homoscedastic) (Enders, 2014; IHS Markit, 2017). From table 9, the test showed an insignificant p-value of more than 0.05, which fulfilled the econometrics' stability (see table 9). This result has proven the robustness time frame model.

Table 9: Heterocedasticity Test

Date: 08/07/21 Time: 18:52

VEC Residual Heteroskedasticity Tests (Levels and Squares)

Sample: 2003Q1 2019Q4

Included observations: 65

Joint test:

\begin{tabular}{ccc}
\hline \hline Chi-sq & df & Prob. \\
\hline \hline 66.27290 & 96 & 0.9911 \\
\hline \hline
\end{tabular}

Individual components:

\begin{tabular}{lccccc}
\hline \hline Dependent & R-squared & $\mathrm{F}(16,48)$ & Prob. & Chi-sq(16) & Prob. \\
\hline \hline res1*res1 & 0.172836 & 0.626851 & 0.8461 & 11.23435 & 0.7948 \\
res2*res2 & 0.181672 & 0.666010 & 0.8116 & 11.80865 & 0.7570 \\
res3*res3 & 0.082821 & 0.270897 & 0.9969 & 5.383333 & 0.9935 \\
res2*res1 & 0.128177 & 0.441066 & 0.9622 & 8.331510 & 0.9384 \\
res3*res1 & 0.087078 & 0.286150 & 0.9958 & 5.660046 & 0.9914 \\
res3*res2 & 0.105078 & 0.352249 & 0.9872 & 6.830098 & 0.9764 \\
\hline \hline
\end{tabular}

Source: Constructed from the data 


\section{Conclusion}

This study aims to evaluate the different implications of mergers and acquisitions (M\&A) and Greenfield foreign direct investment in the monetary transmission mechanism effects on the growth of gross domestic product per capita (GDP per capita) in Indonesia Our findings demonstrate the complementary functions of M\&A and Greenfield investment respectively in the short-term and long-term on the growth of GDP per capita in Indonesia. These findings provide some academic and practical implications. Greenfield investment is a mediator for M\&A to induce more domestic investment and GDP growth per capita. The academic implication is to reject the dichotomy of M\&A and Greenfield investment on economic growth as shown in the past international economic debates. Meanwhile, in practice in economic development policy, the synthesis of this study reveals more balanced considerations of M\&A and Greenfield investment on economic development in Indonesia.

The limitation of this study is that the observation was specific to Indonesia. Other studies can replicate the transmission mechanism effects of M\&A and Greenfield investment in other Southeast Asian countries to echo that common pattern. Besides, other econometric experiments may add other mediated variables such as inflation that may arise as the capital injection expands to host countries.

For Indonesian economic development policies, the policymakers can devise policies to enhance the influx of M\&A and Greenfield investment based on the time horizon objectives. However, the priorities should be carefully examined as to what is required for economic development, whether short-term improvement or sustainable long-term economic spill over to the Indonesian economy.

\section{References}

Aguiar, M., \& Gopinath, G. (2002). Fire-sale FDI and liquidity crises. Review of Economics and Statistics, 87(1999), 1-5. https://doi.org/10.2139/ssrn.323260

Ashraf, A., Herzer, D., \& Nunnenkamp, P. (2016). The Effects of Greenfield FDI and Cross-border M\&amp;As on Total Factor Productivity. The World Economy, 39(11), 1728-1755. https://doi.org/10.1111/twec.12321

Bair, J. (2005). Global Capitalism and Commodity Chains: Looking Back, Going Forward. Competition \& Change, 9(2), $153-180$. https://doi.org/10.1179/102452905X45382

Balsvik, R., \& Haller, S. A. (2010). Picking "Lemons" or Picking "Cherries"? Domestic and Foreign Acquisitions in Norwegian Manufacturing*. Scandinavian Journal of Economics, 112(2), 361-387. https://doi.org/10.1111/j.1467-9442.2010.01606.x

Baumgarten, D., Geishecker, I., \& Görg, H. (2013). Offshoring, tasks, and the skill-wage pattern. European Economic Review, 61, 132-152. https://doi.org/10.1016/j.euroecorev.2013.03.007

Blomström, M., \& Sjöholm, F. (1999). Technology transfer and spillovers: Does local participation with multinationals matter? European Economic Review, 43(4-6), 915-923. https://doi.org/10.1016/So014-2921(98)00104-4

Calderón, C., Loayza, N., \& Servén, L. (2004). Greenfield Foreign Direct Investment and Mergers and Acquisitions: Feedback and Macroeconomic Effects. The World Bank. https://doi.org/10.1596/1813-9450-3192

Cavusgil, S. T., Knight, G., \& Riesenberger, J. (2020). International Business: The New Realities (Subscription), 5th Edition (5th ed.). Pearson.

Enders, W. (2014). Applied Econometric Time Series (Wiley Series in Probability and Statistics) 4th Edition (4th ed.). Wiley.

Eren, M., \& Zhuang, H. (2015). Mergers and Acquisitions Versus Greenfield Investment, Absorptive Capacity, and Economic Growth: Evidence from 12 New Member States of the European Union. Eastern European Economics, 53(2), 99-123. https://doi.org/10.1080/00128775.2015.1033240

Gopalan, S., Ouyang, A., \& Rajan, R. S. (2018). Impact of Greenfield FDI versus M\&amp;A on growth and domestic investment in developing Asia. Economia Politica, 35(1), 41-70. https://doi.org/10.1007/s40888-017-0085-Z

Grossman, V., Mack, A., \& Martínez-García, E. (2014). A New Database of Global Economic Indicators. Journal of Economic and Social Measurement, 39(3), 163-197. https://doi.org/10.3233/JEM-140391

Gujarati, D., \& Porter, D. (2008). Basic Econometrics (5th edition). McGraw-Hill Education.

Harms, P., \& Méon, P. G. (2018). Good and useless FDI: The growth effects of greenfield investment and mergers and acquisitions. Review of International Economics, 26(1), 37-59. https://doi.org/10.1111/roie.12302

Hashem, H. (2016). Determinants of Egyptian Banking Sector Profitability: Time-Series Analysis from 2004-2014. International Journal of Business and Economic Sciences Applied Research, 9(2), 73-78.

Hasudungan, A. (2006). Hubungan Dinamis Real Interest Rate Differential, Nilai Tukar Riil \& Cadangan Devisa di Indonesia: 1995-2005. Jurnal Ekonomi Dan Pembangunan Indonesia, 6(2), 83-91. https://doi.org/10.21002/jepi.v6i2.176

Hasudungan, A., \& Raeskyesa, D. G. S. (2021). The Relationship between Oil Palm Expansion and Income Inequality in Indonesia, Malaysia, the Philippines, and Thailand: International Trade Insights. Journal of Entrepreneurship, Business and Economics; Vol 9 No 2 (2021): Online First. http://scientificia.com/index.php/JEBE/article/view?path=

IHS Markit. (2017). EViews 10 Getting Started. IHS Global Inc. http://eviews.com/download/EViews 10 Getting Started.pdf

Jude, C. (2019). Does FDI crowd out domestic investment in transition countries? Economics of Transition and Institutional Change, 27(1), 163-200. https://doi.org/10.1111/ecot.12184

Kriesler, P., \& Halevi, J. (2016). Asia, Japan and the Internationalization of Effective Demand. In Post-Keynesian Essays from Down Under Volume II: Essays on Policy and Applied Economics. Palgrave Macmillan.

Letson, D., \& Carter, D. (2009). Structural Vector Error Correction Modeling of Integrated Sportfishery Data. Marine Resource Economics, 24(1), 19-39. https://doi.org/10.5950/0738-1360-24.1.19

Liu, X., \& Zou, H. (2008). The impact of greenfield FDI and mergers and acquisitions on innovation in Chinese high-tech industries. Journal of World Business, 43(3), 352-364. https://doi.org/10.1016/j.jwb.2007.11.004

Marcellino, M., \& Musso, A. (2011). The reliability of real-time estimates of the euro area output gap. Economic Modelling, 28(4), 
1842-1856. https://doi.org/10.1016/j.econmod.2011.03.014

Marin, A., \& Bell, M. (2006). Technology spillovers from Foreign Direct Investment (FDI): the active role of MNC subsidiaries in Argentina in the 1990s. Journal of Development Studies, 42(4), 678-697.

Marin, A., \& Sasidharan, S. (2010). Heterogeneous MNC Subsidiaries and Technological Spillovers: Explaining Positive and Negative Effects in India. Research Policy, 39, 1227-1241. https://doi.org/10.1016/j.respol.2010.06.001

Mills, T. (2019). Applied Time Series Analysis. Academic Press. https://doi.org/10.1016/C2016-0-03956-6

Nguyen, H. T., Luu, H. N., \& Do, N. H. (2020). The dynamic relationship between greenfield investments, cross-border M\&As, domestic investment and economic growth in Vietnam. Economic Change and Restructuring. https://doi.org/10.1007/s 10644020-09292-7

OECD. (2020). Foreign direct investment flowe in the time of COVID-19. http://www.oecd.org/coronavirus/policy-responses/foreigndirect-investment-flows-in-the-time-of-covid-19-a2fa20c4/

Pesaran, M. H., Shin, Y., \& Smith, R. J. (2000). Structural analysis of vector error correction models with exogenous I(1) variables. Journal of Econometrics, 97(2), 293-343. https://doi.org/10.1016/So304-4076(99)00073-1

Radulescu, M., Cirstea, C. G., \& Belascu, L. A. (2020). FDIs and Commercial Balance in CEE Countries - Special Focus on the Manufacturing Economic Sectors. A VAR Analysis. International Journal of Business and Economic Sciences Applied Research, 13(2), 7-18. https://doi.org/10.25103/ijbesar.132.01

Raeskyesa, D. G. S., \& Suryandaru, R. A. (2020). Competitiveness and FDI Inflows in ASEAN Member Countries. International Journal of Business and Economic Sciences Applied Research, 13(1), 14-20. https://doi.org/10.25103/ijbesar.131.02

Song, H., \& Witt, S. F. (2006). Forecasting international tourist flows to Macau. Tourism Management, 27(2), 214-224. https://doi.org/10.1016/j.tourman.2004.09.004

The World Bank. (n.d.). World Development Indicators. Retrieved December 10, 2020, from https://databank.worldbank.org/home

UNCTAD. (n.d.). World Investment Report. Retrieved December 13, 2020, from https://unctad.org/topic/investment/worldinvestment-report\#: :text=The World Investment Report has been published annually,topic related to foreign direct investment and development.

Verico, K. (2008). The Impact of ASEAN's Intra-trade to FDI Inflows from Non-Member States: The Cases of Indonesia, Malaysia and Thailand 1987-2006. Economics and Finance Indonesia, 55(3), 253-280.

Verico, K., \& Pangestu, M. (2020). The Economic Impact of Globalisation in Indonesia (No. 338; ERIA Discussion Paper Series). https://www.eria.org/uploads/media/discussion-papers/The-Economic-Impact-of-Globalisation-in-Indonesia.pdf

Wang, M., \& Wong, M. C. S. (2009). What Drives Economic Growth? The Case of Cross-Border M\&A and Greenfield FDI Activities. Kyklos, 62(2), 316-330. https://doi.org/10.2139/ssrn.627663

$\mathrm{Xu}, \mathrm{R} ., \mathrm{Xu}, \mathrm{L} .$, \& Xu, B. (2016). Assessing CO 2 emissions in China's iron and steel industry: Evidence from quantile regression approach. Journal of Cleaner Production, 152, 259-270. https://doi.org/10.1016/j.jclepro.2017.03.142

This is an Open Access article distributed under the terms of the Creative Commons Attribution Licence

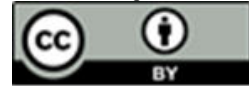

